\title{
MADRASA EDUCATION SYSTEM PROTOTYPE OF CHARACTER EDUCATION MODEL Case Study at MTs and MA Assalam Kudus 2018
}

\author{
Supaat dan Taufikin \\ IAIN Kudus, Indonesia \\ supaatkudus@yahoo.com \\ taufikin@stainkudus.ac.id
}

\begin{abstract}
The purpose of this study was finding the model of character education in MTs and MA NU Assalam Kudus. This case study used qualitative approach with the inductive phenomenology. The data was collected using interview, observation and documentation. It was analyzed through some stages. They were data collection, data reduction, data display and conclusion. The results of this study indicated that: 1) the concept of character education in MTs and MA NU Assalam is based on environmental integration by developing academic religious characters namely religiosity, sincerity, exemplary, and loving the goodness of honesty, discipline, responsibility, communicative, and self control; 2) System of character education planning is based on a systemic-integrative model. The system is implemented in a way formation of a conducive environment (biah), habituation, personification, role model, integration of extracurricular and intracurricular activities and programs. The surveillance system uses internal control management through regulation and attitude book, and external through home visit.
\end{abstract}

Keywords : Character education, environmental integration, Madrasa. 


\section{A. Introduction}

Islamic institutions, especially madrasa (Islamic school) should apply the concept of character education that will be raised through the implementation of good education management systems so that it will give the maximum implication. The character is developed refers to the national education system law which consists of 18 national characters. This is done through a good management system. It covers planning, implementation and supervision. Clear character and target through a good management system will give good implications.

Character education has become a polemic in various countries, including Indonesia. The views of pro and contra characterize the discourse of character education for a long time. Actually, character education is an essential part of being a school assignment, but so far it gets less attention. Due to the lack of attention to character education in the realm of schooling, it has led to the development of various social problems for society, such as the destruction and retreat of morals, akhlak, and ethics (Thomas Lickona, 2013: 9).

Children brawl and fight in the street, even it can happen among villages that take lives and property, and other cases seem to reverse logic as if this nation does not have enough civilization and moral ethics that can be an antidote to bad and destructive behaviors. Noble values such as honesty, courtesy and friendliness, togetherness, and religious behavior seem to be eroded by the "new culture" that is hedonistic, materialistic, and individualistic. As a result, this nation seems to never get an education on how to become a good citizen and society. Whereas in fact, they have received moral and religious education from the level of basic education to university or college education.

The question is "what is wrong with our education system?". This question becomes relevant and important because the purpose of education is to prepare students to be good individuals and character. If that is the reality, it means that our system and practice of education has failed to achieve its objectives. Because it refers to the goals of national education, Indonesian people who have received education should be believers and mutaqqin who are certainly noble. 
People who have faith, piety and morality cannot do things that are forbidden by religion, but instead will do all the good things that are instructed in religion. The occurrence of various violations and deviant behaviors indicates that the norms or teachings received by students are limited to knowledge (cognitive) that do not positively correlate in attitudes and actions. It means that the quality of learning in madrasa has not touched the important domain which is actually an educational goal, namely affection and noble psychomotor .

The rapid movement of educational institutions, especially MTs and MA Assalam in Kudus in their efforts to produce graduates with noble character. It can be done through a good management system: planning, implementation and supervision. The involvement of a Kiai as the main actor in all management processes and functions with the principals, deputy heads, homerooms and teachers and involving the guardians of students, has provided preliminary data that will be more challenging for researchers to explore in detail in this study. MTs Assalam has been established since 2002 and MA Assalam 2005 with an integrated environment pesantren, have applied boarding system with a better value system amid the pro and contra of full day school that becomes discourse over the years.

This field research tried to find more details regarding the character education system applied at MTs and MA Assalam Kudus with a focus on the developed character concept and management system used with the phenomenology approach, with inductive thinking framework. Data was taken by observation, interviews, and documentation with the main source of leadership of the Assalam Foundation, Madrasa Headmaster, Deputy Heads, Teachers and Students. Data from the research results were found by data collection, data reduction, presentation and conclusion. In the end of this research will spawn a concept or model of the character education system from the combination of MTs and MA Assalam Kudus which have implemented a boarding school system.

\section{B. Discussion}

The discussion of the research findings produced a reconstructed concept which is made into propositions as substantive and formal theoretical findings. This section is discussed sequentially 
in accordance with a focus on: (1) the concept of character values developed in MTs and MA Assalam Kudus, (2) the system of planning, implementation and oversight of character education in MTs and MA Assalam Kudus, (3) the implications of character education in MTs and MA Assalam Kudus, (4) the conceptual edifice of research findings.

\section{Profile of MTs and MA Assalam Kudus}

As an educational institution, MTs and MA Assalam and their Islamic Boarding Schools have the same vision and mission as well as goals, contained in a place, with management integrated in a Shubulus Salam Assidiqiyyah Foundation.

\section{a. Vision, Mission and Objectives of MTs and MA NU Assalam Kudus}

The Vision of MTs and MA NU Assalam Kudus is "Towards Students with Noble Morals, artifical, Creative, Innovative and Imtaq Insight and Science and Technology". Meanwhile, the Mission is "Organizing Education to Grow the Spirit of Learning, Scientific Thinking, Based on the Ahlussunnah Insightful Shariah”. And, the aims are:

1. Optimizing the learning process by using an active learning approach

2. Increasing the use of foreign languages (Arabic and English as communication materials and introductory material for a number of suitable subjects.

3. Developing the academic potential of students' interests and talents through counseling services and extracurricular activities

4. Familiarizing Islamic behavior in the madrasa environment

5. Increasing academic and non academic achievements of students in the field of art and sports through championships and competitions

6. Improving the quality of educator resources and education personnel through coaching, upgrading, awards and others 
7. Realizing student guidance on good career guidance that allows students to solve problems well and get a good career in the future

8. Realizing good school management

\section{b. A Brief History of MTs and MA NU Assalam Kudus}

Assalam Kudus is an educational institution characterized by ahlussunnah wal-jama'ah in which there are Assalam Islamic Boarding Schools and Madrasa (Madrasa Tsanawiyyah and Madrasa Aliyah). The system education and teaching developed at this institution is a combination of the system of pesantren (Islamic Boarding) with the developing of national education, in other words the classical system based on the curriculum from the Ministry of Religion, the National Education System and the Mararif Educational Institution, including skills education.

Assalam Kudus was established on the 20th of Rabiuts Tsani or coincided with June 30, 2002 by KH. Maruf Siddiq, Lc alumni of the Islamic University of Medina, Saudi Arabia. Its founding history began when he performed the pilgrimage to the Kudus land Makkah Al Mukaromah in early 2002 met with Syeh Hamzah Abdussalam, a resident of Mecca whose house had been occupied by Kyai Ma'ruf while he was studying secondary in Mecca. Because they had not met for a long time, they talked about their respective activities. Finally, Syeh Hamzah encouraged Kyai Ma'ruf to establish an educational institution so that he could devote himself as an educator to his old age. For this purpose, Syeh Hamzah provided donation of five hundred million rupiah.

After the coming of Kyai Ma'ruf from the Hajj, he began to think and design the forms and models of education that were appropriate to be developed. Through tafakkur, Kyai finally became interested in an integrated pattern between the education of Islamic Boarding Schools and Madrasa in one management.

Finally, in mid-2002, there are a mosque, six classrooms, Islamic boarding schools, educational facilities and other facilities, as the beginning of the establishment of 
Assalam as well as the commencement of the educational process in Islamic Boarding Schools and Madrasa Assalam. The name Assalam itself was taken from the last name of Syeh Hamzah Abdussalam as a tribute to him.

Madrasa Assalam is located in the village of Tanjungkarang, Jati Subdistrict, Kudus Regency, and now there are 288 Aliyah students and 452 Tsanawiyah students who are studying. From that number, more than $50 \%$ of students are santri from Assalam Islamic Boarding School. The rest are students from communities around the madrasa who do not live in boardingschool or nglajo (commuting).

\section{The Concept of Character Values developed at MTs and MA Assalam Kudus}

Good character values developed to be a superior, moral and moral person. Thomas Lickona and William Kilpatrick said that there are three pillars/ dimensions of characters that must exist in developing a winning character, namely: (1) having good moral knowledge (moral knowing), (2) having a good awareness and capability ( moral feeling), and (3) having good moral actions (Thomas Lickona, 1992: p. 52 and William Kilpatrick in Abdul Majid and Dian Andayani, 2011: p.31-35).

The principle of three pillars/dimensions of superior character contains five ranges, namely: (a) attitudes and behavior in a vertical relationship (hablum minallah) with God Almighty, (b) attitudes and behaviors in a horizontal relationship (hablum minannas) with yourself, (c) with family, (d) with society and nation, and (e) with the surrounding environment.

Furthermore, Thomas Lickona suggested seven elements of core character education values, namely: (1) honesty (2) compassion, (3) the courage, (4) love (kindness), (5) self control, (6) cooperation, and (7) deligence or hard work (Thomas Lickona, 1992: p. 50). Those seven core characters, according to Thomas Lickona, are the most important and fundamental that must be developed and accustomed to students in addition to other values. In general, this theory can be said to arise based on the view that human 
existence must be interpreted in relation to noble mind and character which must be preserved and maintained.

The government established or development of character values in MTs and MA Assalam Kudus conducted through the internalization of values into a personal character that is superior to developed the concept of the academic religious character education, which values: sincerity, trust, tawadhu', compliance, trust, piety, exemplary, caring for the environment, love of cleanliness, honesty, discipline, communicative, loving kindness, discipline, responsibility, communicative, and self-control. The development of these religious academic values uses the principle of integration of moral knowing, moral feeling and moral action through exemplary approaches and systems approaches, strengthens the theory of Thomas Lickona and William Kilpatrick above, that superior character is formed through a combination of three moral knowing, moral feeling and moral action which support each other in the formation of superior character, therefore, the implementation must not be carried out separately in realizing academic religious character .

The activity of forming/developing character values requires a systems approach in order to achieve goals and objectives effectively. In line with Thomas Lickona's theory the method used is a comprehensive approach that reveals the elements that must be applied to students with seven elements of character education values, as mentioned above, namely: (a) honesty, (b) mercy, (c) courage, (d) compassion /kindness, (e) self control, (f) cooperation (cooperation), and (g) deligence or hard work (Thomas Lickona, 1992: 50). Those seven core characters, according to Thomas Lickona, are the most important and fundamental that must be developed for students, in addition to other values. In general, this theory rests on the view that human existence must be interpreted in relation to noble character.

Based on the explanation above, the activities of planning character education at MTs and MA Assalam Kudus have developed character values, whether it is through extracurricular, intra and cocurricular activities. 


\section{Planning, Implementation and Supervision System of Character at MTs and MA Assalam Kudus}

\section{a. System of Planning for Character Education at MTs and MA Assalam Kudus}

As stated by George R. Terry, planning is the whole process of thinking to determine all activities that will be carried out in the future in order to achieve the goal. For this reason, the ability to carry out visualization and looking forward is needed to form a pattern of action to realize the quality of graduates (George R. Terry, 1986: 72).

The relation to the character education system in this study is that character education planning in madrasa is a process of planning, implementing and supervising character education to realize the quality of graduates in accordance with the vision, mission and goals of the madrasa or even the expectations of society.

As an education system, character education also consists of elements of education which will then be managed through the fields of planning, implementation and supervision. Elements of character education that will be planned, carried out and controlled or supervised include: (a) character values competence of graduates, (b) content of curriculum character values, (c) character values in learning, (d) character values of education and education personnel, and (e) character values of educational teaching.

Referring to George R. Terry planning theory above, it can be seen in MTs and MA Assalam Kudus that every element seemed very enthusiastic in performing their duties and obligations as a madrasa principal, teacher (homeroom, subject teachers and the guidance counselor), students, and as citizens of formal and structured educational institutions in order to achieve goals corresponding character education planning. Therefore, in order not to deviate from the goal, it is very important for schools and madrasa through planning, how to visualize character education, looking forward to planning a pattern of action in realizing the quality of graduates.

The elements of character education planning at MTs and MA Assalam Kudus which cover how the planning activities are, who is involved in the planning and how the planning process is decided in the program of madrasa with character education. All activities 
that support character education programs, such as: management of students, regulation of madrasa, human resources, facilities and infrastructure, finance, library, learning, assessment, and management others already planned in early, strengthen theory George R. Terry that planning is an activity of making decisions about the objectives (objectives) what will be achieved, what actions will be taken in order to achieve the goals or objectives and who will carry out their duties (George R. Terry, 1986: 86).

As a madrasa that has implemented and developed character education with school management, MTs and MA Assalam Kudus develop character education programs by carrying out the stages of management functions effectively. The effectiveness of planning in character education at MTs and MA NU Assalam Kudus is based on the stages of the planning process carried out by this madrasa is to develop a strategic plan for character education. Planning is a certain cycle and through this cycle a plan can be monitored from the beginning of preparation until the completion of the planning.

According to Luth Gulick, the function of planning is seen as a field of knowledge that systematically seeks to understand why and how people work together through ways of regulating human resources. Generally, MTs and MA Assalam Kudus have undertaken steps: (a) planning with a complete and clear purpose in meeting with the foundation leadership; (b) existence formulas action that will be done; (c) analysis and determination of ways and means to achieve objectives within the framework of implementing planning; (d) appointment of people responsible for implementation including the chairman of the foundation in conducting supervision; (e) determining a system that allows measurement of achievements based on certain criteria.

Thus, based on the elements and steps in the planning of the above theories, it can be concluded that the planning process is a process that is recognized and needs to be carried out integratively and sequentially because the order is a rational process as a property character building. The researchers carefully studied character education planning refer to the strategic plan and the national education unit. Strategic plans are prepared by the leadership of the foundation, for example by inviting principals to compile a one-year 
madrasa program, the material discussed at the meeting includes program plans, program details, then the madrasa head prepares a joint work program with all elements of the madrasa including: (1) the head of the madrasa as the person in charge of the program, (2) activities, (3) indicators of success, (4) steps of achievement, (5) being responsible for activities, (6) time of implementation, and (7) financing the program implementation. Furthermore, the program that has been arranged is submitted to the foundation to get approval and ready to be held.

Thus, the goal of character education can be achieved by: (a) basing on facts and proven truth, (b) the results of imagination and thought, (c) considering the possibilities of difficulties faced and preparing a solution, (d) leading to change. Therefore, in the preparation of character education programs, it is necessary to have a futuristic vision. As stated by Muhaimin, the vision of the madrasa is a distant goal that must be achieved by the madrasa within a certain period of time (Muhaimin, et al, 2011:155).

Based on the description above, in character education planning activities it is necessary to have transformational dreamers/principals in empowering madrasa citizens. The head of a transformational madrasa motivates subordinates to do more than what is actually expected, not just subordinates to follow the directions given.

Both MTs and MA Assalam Kudus have carried out the stages in planning. The character education planning system is based on a systemic-integrative model, for example before a character education program is implemented, the principal makes a strategic plan to be discussed in work meetings with the teacher council to get approval.

\section{b. The Implementation of Character Education at MTs and MA Assalam Kudus}

According to Kontz and O'Donnel, the function of the implementation is a close relationship between individual aspects arising from the arrangement of subordinates to be understood and the division of labor that is effective and efficient for achieving real organizational goals (Harold Kontz and Cyril O’Donnel, 1990: 35). In this case, as in the findings of Nalam Assalam Kudus MTs and MA, the establishment of a conducive environment (biah) then applies 
the exemplary approach (uswatun hasanah) and system approach in developing character values through: habitualization (habituation), formation/the development of character values by getting used to the daily lives of students in class, madrasa and home; personification, manifestation of character values in everyday attitudes and behavior, both vertically (hablum minallah) in relation to God Almighty, or horizontally (hablum minannas) in relation to self, other people, family, the community and the surrounding environment; models of someone's behavior (role models), especially teachers (homeroom teacher, subject teacher and counseling teacher) who have strategic roles that are guided and emulated to be role models of attitudes and behaviors for their students; integrating extracurricular, intra and cocurricular activities and programs.

Thus, the implementation carried out by the principal, the teacher (homeroom teacher, subject teacher and counseling teacher) is very important in management. Head of madrasa, teacher (homeroom teacher, subject teacher and counseling teacher) as capable manager moving his subordinates in the implementation certainly has certain tips, such as giving motivation and an effort to arouse the morale of his subordinates.

Because of this dominant human element, a madrasa head in carrying out his duties must pay attention to three things, namely: (a) paying attention to human elements in all managerial actions and problems; (b) seeking information about the needs of each school/ madrasa citizen and trying to meet these needs; (c) paying attention to the needs and interests of participating and involved groups (George R. Terry, 1986: 106).

At this stage, character education is carried out through the development and learning and learning experiences that lead to the formation of character values in students. This process is carried out through a process of empowerment and civilization of character values through the formation of the environment, habituation, embodiment, exemplary and integration, as outlined as one of the principles of implementing national education.

Based on the finding, the implementation of character education at MTs and MA Assalam Kudus through three aspects, namely: (1) through teaching and learning activities, how to 
familiarize (habitualize) character values in the daily lives of students, develop the role of behavioral values (role model), (2) through the madrasa environment, how the manifestation of character values in student attitudes and behavior (personification), models of good behavior by teachers and all citizens of the madrasa, and (3) through the integration of extracurricular, intra and co-curricular activities and programs in building learners character.

Implementation of character educaton in MTs and MA Assalam Kudus is done in synergy between the formal activities at the school with diniyah/outside madrasa (at home and in schools) conducted by the approach uswah hasanah and systems approach, namely by: (a) integrating planned character education content into all subjects, (b) integrating character education into daily activities in madrasa and in pesantren, (c) integrating character education into programmed or planned activities, and (d) establishing collaborative communication between madrasa and parents or guardians of students .

As E. Mulyasa said, the implementation of character education generally emphasizes exemplary, creating a conducive and habituating school environment, as well as through various sciences and activities (E. Mulyasa, 2013:9). The implementation of character education at MTs and MA Assalam Kudus is more directed at the formation of a madrasa culture, namely the values that underlie behavior, traditions, daily habits and symbols that are served by all citizens of the madrasa by playing their respective roles (role model). Madrasa culture is a characteristic of the character and image of the madrasa in the wider community. Implementation is an activity to realize the plan into concrete actions in order to achieve goals effectively, so that they will have values.

In the implementation of character education which is a core activity of character education, it is carried out in madrasa, taken through four integrated alternative strategies: (a) integrating character education content that has been formulated into all subjects, (b) integrating character education into daily activities in madrasa, (c) integrating character education into programmed or planned activities, (d) establishing cooperative communication between madrasa and parents of students. 


\section{c. Supervision of Character Education at MTs and MA Assalam Kudus.}

Supervision is a way for institutions to realize effective and efficient performance and quality and it further supports the realization of the vision, mission of an institution or organization. The elements of supervision, namely: (a) the process in determining the work that has been and will be done, (b) as a tool to get people to work towards the goals that want to be achieved, (c) monitor, assess and correct the implementation of work, (d) avoiding and correcting the errors, irregularities or misuse, (e) measuring the level of effectiveness and work efficiency.

Oversee activities in accordance with a predetermined plan must take steps in carrying out supervision: (1) setting the standard implementation, (2) measuring the actual performance, (3) measuring the actual implementation and comparing it with the standard set, (4) taking corrective actions needed if the implementation deviates from the standard (George R Terry, 1986: 37).

Supervision of character education at MTs and MA NU Assalam Kudus includes two aspects, namely: process and results. In general, supervision of character education is associated with efforts to control, foster, and improve as a quality control of graduates in a broad sense. Through effective supervision, the wheels of the organization, implementation of plans, policies, and quality control efforts can be carried out better. Supervision at MTs and MA Assalam Kudus uses internal control management through the attitude book, and boardingschool regulations implemented by the madrasa, undergoing the control function of internal control management attitudes through order, and external control by collaborating with parents to control attitudes and the behavior of students at home through home visit.

Furthermore, supervision of character education at MTs and MA NU Assalam Kudus is as follows:

1. Supervising the implementation of the character education program on a regular and continuous basis in order to be able to monitor every stage of the development of the attitudes and behavior of the character of students in the madrasa; 
2. Supervising every attitude and behavior of student character values by prioritizing conseling teachers and regulations/rules to control the quality of graduates large;

3. Supervising every attitude and behavior of students' character values to see the possible constraints that occur in the implementation of the program and identify problems;

4. Supervising by analyzing data found in the field to prepare recommendations related to the development of education programs character implementation;

5. Supervising to measure the level of success of the implementation of character education programs at/ madrasa.

6. Supervising by controlling cooperation through parents of students to monitor the development of students' attitudes and behaviors at home through home visit.

From the above description, MTs and MA Assalam Kudus have used a well managed education system to achieve the goals of character education programs, starting from the system of planning, implementing and supervising character education.

\section{Implications of Character Education Model at MTs and MA NU Assalam Kudus}

Based on field data, it was found that the implications of the character education system in MTs and MA NU Assalam Kudus included three things: First, for the madrasa policy in the form of a character-based curriculum, a set of rules for habituation processes and targets is achieved; Second, for an integrated character education system; Third, for students to have academic religious character, that is having an awareness of realizing the values of quality character that are faithful and pious, loving science, doing good deeds, selfconfidence, noble character and contributing to society, according to expectations, satisfaction, pride and trust society.

Based on the above theories, in the formation/development of character education in MTs and MA Assalam Kudus, it was 
pursued through four alternative strategies integratively, namely: a) integrating character education content that has been formulated into all subjects. b) integrating character education into daily activities in madrasa, c) integrating character education into the activities that are programmed or planned, and d) establishing communication, cooperation between madrasa and parents of students through a home visit.

The implication of the character education system lies in the madrasa policy which adheres to the commitment to develop character education programs based on the vision and mission of the madrasa. Therefore, the curriculum is character-based and supported by a set of process regulations habituation and targets achieved, an integrative management system, and the realization of character attitudes and behaviors. They must have an awareness of realizing the values of character that are faithful and pious, love science, do good deeds, have self-confidence, noble character, contribute to society, make the community satisfied and proud of them, and gain public confidence. Those indicators are measured from the needs of customers or the public. And, it is strengthened by the theory of Edward Sallis that quality is based on the customer. The qualifications are: (a) customer satisfaction, (b) exceed customer expectations, and (c) enlighten customers (Edward Sallis, 2002: 54).

The implications for the character education system in MTs and MA Assalam Kudus which began with the creation of an integrated environment and habitualization of the values of character education were taken through an exemplary approach and a system approach, as following:

1. The teachers give example whether they are in class or outside the classroom;

2. Creating environmental care how the school/madrasa environment always reflects a good environment so that students grow and have good characters ;

3. Turning on control of the behavior of students in daily life in schools/madrasa;

4. Giving benefits to the surrounding so that students are also responsible for how their behavior can be beneficial to their environment; 
5. Practicing character values through various Madrasa activities;

6. Instilling the tradition of cooperation in building character;

7. Awareness of character values does not only reflected by having knowledge but also awareness to practice values they said;

8. Familiarizing students with self-introspection (muhasabah);

9. Involving parents/guardians of students and the community.

Based on the above implications, it is clear that the approach done by MTs and MA Assalam Kudus in developing students' character values has implications for daily habits based on character values developed at MTs and MA Assalam Kudus, which have implications for the realization of academic religious character as follows:

\section{a. Faith and devotion}

The quality of graduates are faithful and devoted, able to read the Qur'an and understand it, have a noble character, understand Islamic jurisprudence, are used to performing daily worship, are able to deliver simple lectures, and are able to take i'tibar or lessons from Islamic history. In addition, students are also able to: (1) increase the faith and piety that have been implanted in the family, (2) channel their talents and interests and develop it in a manner optimally, (3) improve the practice of Islamic teachings, (4) counteract the negative influences of other beliefs or cultures that endanger beliefs, (5) adjust to the physical and social environment to be in line with Islamic teachings, (6) make Islam a life guide to achieve happiness in the world and hereafter, (7) able to understand Islam as a whole in accordance with the absorption of students and the time they have.

MTs and MA Assalam Kudus develop and familiarize students with the character of "faith and devotion" where and whenever they are. So the teachers teach students how they live obediently to follow all the commands of Allah SWT and abandon all His prohibitions. School/madrasa always emphasizes the daily lives of students based on the guidance of the Qur'an and Hadith of the Prophet SAW whether by delivering it in class, outside the classroom or posting/ showing on the walls of the school/madrasa. 


\section{b. Loving the Science}

The learning environment of students in MTs and MA Assalam Kudus is conditioned to last throughout life (life long education), students spend time with a lot of learning driven by the character of "loving science", for which the school/madrasa environment has been set up lead and condition of the students that always learn wherever and whenever they are.

\section{c. Charity Righteousness (Shalih)}

Character "charity righteousness" involves all the smallest acts done by students with the intention because Allah SWT is called a" good deed "character. The character of "good deeds" is simple; doing good in accordance with religious teachings and showing good behavior in daily life, such as the attitudes and behavior of students in MTs and MA Assalam Kudus to the rules/regulations in the school/ madrasa that are full of obedience to Allah SWT and awareness in order to train, shape self-attitudes to be better, not come late, collect assignments according to the specified time, wear uniforms according to religious regulations, respect others as fellow servants of Allah SWT, respect, obey teachers and parents' advice, train one's ability to be more able to develop themselves, behave with full awareness if they violate the rules, then there will be logical consequences as a result of violations of rules/order.

\section{d. Self Confidence}

The "confident" character of students who are cultivated in MTs and MA Assalam Kudus, namely characters that are not easily shaken by the influence of others. Students have their own attitude based on the establishment of knowledge and beliefs. They make decisions and do the best for religion, self , the community and the environment.

\section{e. Character}

The character values in MTs and MA Assalam Kudus are related to how the efforts of students avoid lying and take actions that do not harm themselves or others in any form. Students always guide themselves to have noble character so that they can become part of the character students, and encourage themselves to cultivate good 
behavior, based on the value system, such as telling the truth, faith, honesty, humility and avoiding pride.

Based on research data in the field, MTs and MA Assalam Kudus have their own peculiarities in developing character values. For example, character education that is emphasized in the madrasa environment must have implications for the daily lives of students, whether when they are in the madrasa or in the boarding school.

\section{Analysis of Character Education Systems at MTs and MA NU Assalam Kudus}

Based on the findings, there is a unification of vision, mission and character values developed at MTs and MA NU Assalam. This is very reasonable because both have different backgrounds and ideals regarding existence institution.

Implications of the vision and mission are still bounded by the chairman of the foundation. That is, the head of the madrasa as a leader has a low authority in translating the vision and mission of the madrasa because every madrasa program in achieving the vision and mission of the madrasa, both long-term and short-term programs must be consulted with the leaders of the foundation .

Character values developed in MTs and MA Kudus Assalam, which begins with creating an environment (biah) education conducive, then apply the value of pesantren (sincerity, trust, tawadhu', obedience, istiqamah, exemplary, caring for the environment, love of cleanliness, honesty, discipline, and responsibility).The values are very decisive in the madrasa because by applying character values in the life of the madrasa, the teachers, employees, and students will be motivated to work together to become a quality madrasa.

The character education system at MTs and MA Assalam Kudus, is part of the efforts of principals/madrasa to improve human beings with character. The steps taken by the principa /madrasa are formulating the vision, mission and developing character values, involving all elements of the madrasa, including teachers, employees, committees, and parents/guardians of students, who always coordinate with the chairman of the foundation. In terms of implementation and supervision, the madrasa develops character education values by creating a conducive madrasa environment, increasing madrasa 
resources and fostering effective communication with all madrasa residents including teachers and parents of students.

\section{Conceptual Construction of Research Finding}

Researcher can formulate a conceptual research findings regarding the system of character education as follows:

Character education system in schools/madrasa is about how character education is planned, carried out and monitored in school/madrasa activities adequately. The formation/development of character values rests on the vision and mission, then applies the character of education with character, through the realization of a conducive educational environment. Creating an environment in this context means integrating MTs-MA and Islamic Boarding in Assalam, then developing values: religiousity, honesty, discipline, responsibility, good communication, self-control, sincerity, exemplary, loving kindness, development in using the principle of integration moral knowing, moral feeling and moral action through exemplary approaches and system approaches. By having dimensions of moral knowing, moral feeling and moral action, students are able to become superior individuals.

These character values are programmed and developed with a system of planning, implementation and supervision by organizing extracurricular, intra and co-curricular learning through: (1) an integrated character education planning system, (2) a system of implementing character values through habitualization daily attitudes and behaviors of students in school/madrasa, personification, manifestation of character values in the daily lives of students, role model, integration of extracurricular, intra and co-curricular activities, programs and formation of the conducive environment (bi 'ah ), (3) a system of monitoring attitudes and behaviors of character values in daily learners on a regular and continuous basis in order to monitor every stage of development of attitudes and behaviors of character values of students, and supervision of attitudes and behaviors in daily learners using internal control management through order and attitude books, as a means of controlling student attitudes and behavior, as well as external control cooperation with parents through a home visit so that students are able to consciously 
and responsibly increase faith and piety, science love, good deeds, confidence, virtuous character and contribution to society, so that the formation of students' character is able to apply in madrasa, pesantren and at home. The values of the character of students who are intact, integrated and balanced are in accordance with the competency standards of graduates that have broad implications for school/madrasa policy. Those are the establishment of characterbased curriculum, set of rules for habituation processes and targets achieved integrated character education management system, and learners become religious and academic, have the awareness to realize the character values, the quality of faith and piety, love science, charitable pious, confident, virtuous noble character, contribute to the society, and get public trust. In simple terms, it can be presented in the chart as follows:

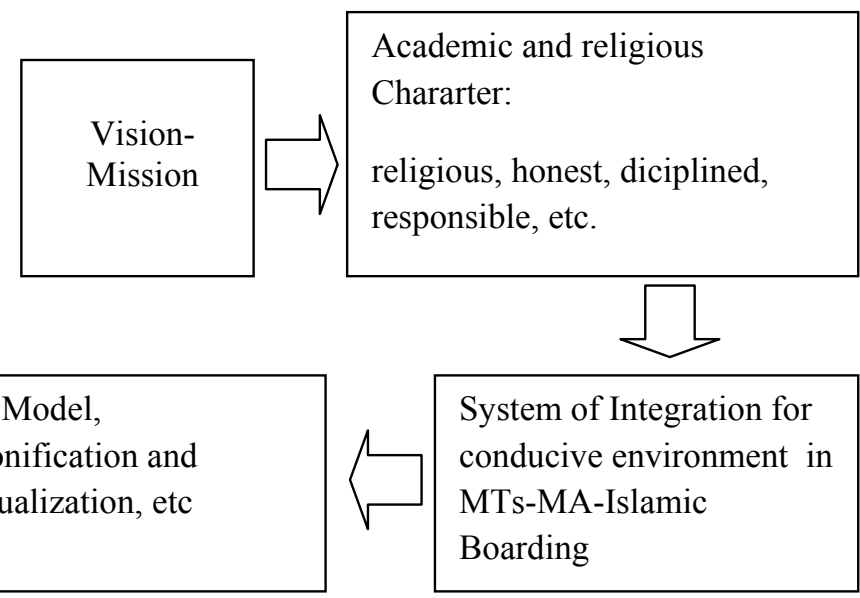

\section{Conclusion}

Based on the results of an analysis about the character education system In MTs and MA Assalam Kudus Academic Year 2017-2018, some conclusions and suggestions are:

1. The concept of character education developed is initiated by establishing a conducive environment, applying values of sincerity, trust, tawadhu', obedience (ta'at), istiqamah, exemplary, honesty, responsibility, habituation to care for the environment and love of cleanliness ; 
2. The character education planning system is based on the system integration model. The implementation uses habitualization (habituation), personification, the model of kyai as role model, the integration of extracurricular activities and programs, intra and co-curricular and the formation of a conducive environment (biah). The surveillance system uses internal and external control management. The internal surveillance is done using system orderly and attitude book and the external surveillance is done through home visit ;

3. The implication for madrasa policy is a character-based curriculum, a set of rules for habituation processes and targets achieved; systemic-integrative character education management system; have an awareness of realizing character values: faith and piety, love of knowledge, good deeds, selfconfidence, noble character, and contribution to society, according to society. expectations, satisfaction, pride and trust.

This concept of character education is based on environmental integration, personification, role models and habitualization. 


\section{REFERENCES}

Azra, Azyumardi. 2003. Surau: Pendidikan Islam tradisional dalam transisi dan modernisasi. Jakarta: Logos.

Bloom, B.S. et al. 1979. Taxonomy of educational objectives: The clasification of educational goals. London: Longman Group Ltd.

Echols, John M. and Hasan Sadily 1987. Kamus Inggris Indonesia. Jakarta: Gramedia. Cet. XV.

Emzir.2013. Metodologi Penelitian Analisis Data, Jakarta: Rajawali Press.

Koentjaraningrat. 2007. Sejarah Teori Antropologi I, Jakarta: UIPress.

Kontz, Harold and Cyril O’Donnel. 1990. Principles of Management: An Analysis of Management Function, translated by Hutauruk, Jakarta: Erlangga.

Lickona, Thomas. 1992. Educating for Character: How Our Schools and Teach Respectand Responsibility. New York: Bantam Books. , Thomas. 2013. Pendidikan Karakter: Panduan Lengkap Mendidik Siswa Menjadi Pintar dan Baik, translated by Lita S. Bandung: Nusa Media.

Majid, Abdul and Dian Andayani, 2011. Pendidikan Karakter Perspektif Islam. Bandung: PT. Remaja Rosdakarya.

Moleong, Lexy J. 2004. Metodologi Penelitian Kualitatif, Bandung: Remaja Rosda Karya.

, Lexy J. 2013. Metodologi Penelitian Kualitatif, Cet. 31, Bandung: Remaja Rosda Karya.

Muhadjir, Noeng. 2007. Metodologi Keilmuan: Paradigma Kualitatif Kuantitatif dan Mixed. (ed.v-revisi).Yogyakarta: Rake Sarasin.

Muhaimin, et al. 2011. Manajemen Pendidikan: Aplikasinya dalam Penyusunan Rencana Pengembangan Sekolah/Madrasa. Jakarta: Kencana. 
Mulyasa, E., 2013. Manajemen Pendidikan Karakter. Jakarta: Bumi Aksara.

Muslih, Masnur. 2011. Pendidikan Karakter: Menjawab Tantangan Krisi Multidimensional. Jakarta: Bumi Aksara. 1st Edition.

Musthofa, A. and Aly, A. 1999. Sejarah Pendidikan Islam: Untuk Fakultas Tarbiyah Komponen MKDK. Bandung: PT Pustaka Setia.

Ryan, Kevin and Karen E. Bohlin. 1999. Building Character in Schools. Practical Ways to Bring Moral Instruction to Life. San Francisco. Jossey Bass.

Sallis, Edward. 2002. Total Quality Management in Education, Incisod USA: Stylus Publising.

Sugiyono. 2012. Metodologi Penelitian Pendidikan Pendekatan Kuantitatif, Kualitatif dan RњD, 15th edition, Bandung: Alfabeta.

Tafsir, Ahmad. 2002. Metodologi pengajaran agama Islam. Bandung: PT Remaja Rosda Karya.

Terry, George R. 1986. Principles of Management. Translated by Winardi, Bandung: Alumni. 
Supaat dan Taufikin 